\title{
A CASE OF FOREIGN BODY IN BRONCHUS (ARTIFICIAL TOOTH)
}

\author{
Maru Nagata \\ National Leprosarium, Nagashima Aiseien \\ (Director: K. Mitsuda)
}

\begin{abstract}
A neural-leprosy patient, male, 48-year-old, swallowed by mistake an artificial tooth which was not found by X-ray examination and considered to have been excreted out of the body. But the patient began to complain of severe cough and sputum. The second $\mathrm{X}$-ray examination revealed it in the left bronchial tube, which was picked out by bronchoscopy about 100 days after the accident.
\end{abstract}

\section{気 管 枝 異 物（義 歯）症 例 \\ 長島愛生園（園辰 光田健輔）}

厚生技官永田まる

（昭和29年 7 月15日 受稿）

\section{緒 骨}

義歯が気管，気管枝異物となる事は非常に稀な事でわ なく, 報告例も必ずしも少くない, 私も左気管枝内に吸 引されて異物となつた 1 症例を経験し，顧みて教えられ る事が多いので，諸先䧳の例に追加して御参考に供した いと思う。

\section{症例}

患 者 48才 男子 神経嗮

既往症 41 才より神経瀨発現 44 才（昭和 24 年 1 月 11 日）人園

現病歴並伦現症 昭和 28 年 2 月 1 日午前 1 時頃，20年 来装用し，近来驰綬して外れ易くなつていた下顎の継続 加工歯を誤鱮した事に気付いた。その時義歯は未旧咽頭 に有つたので，吐き出す樣に努力したが，漸次下降する のが自分で感ぜられ作ら如何ともする事が出きず文蕗 辺に圧迫感があり，咳嫩わ無かつた，そとで夜明けを待 つて内科次で耳鼻科に受診したが䔬物は発見されなかつ た。然るにその後軽度でめるが唹嫩が連続し, 食思不振 不眠, 微熟か㟨鳴が現われ, 又時に痰に赤い米屑様の線 状の血液を湿ずるに至つた。以上の様な主訴からして喘 息或は結核性胸部医患の疑もあり, 経過を観察し又諸検 查を行らベく 4 月 1 日大院せしめた。4 月14日の佩部X 線写真（写真 I）矢印に於ては左肺門部に石灰沈着にし
ては大きな文形状が抢かしい陰影が認められたが患者は 2 月 1 日脱落した義歯は䔬便と共に排泄されたるのと思 い込んで居つた為化診察の際口にせず，又私共も義歯の 事を念頭に置いてなかつたので全体として柔かすぎたと のX線写真の陰影を異物と判断し得なかつた。との写真 にはその他著変がなく無気肺もない，僅に軽度の肺紋理 の增强が見られたに過ぎなかつた。5月に大つてから喀 痰が黄色を是し膿性を带びて来たので, 肺に化膿巣があ る筈だと思いペニシリンの注射を初めた。との様な経過 を経て, 連続的の检嫩喀痰 (而も他党的に一見無所見) の原因として 3 ケ月前脱落した義歯に関係が有りはしな いかと気付き, 前回より硬度を硬くした後前位と第二斜 位のX線写真を撮つたととろ, 写真II及IIIの如く, 気管 分岐部より約 6 稉の左気管枝内に義歯の除影を認めた。

依て 5 月15日岡山大学医学部耳鼻科黒任講師の来診を 御願いして，上気管枝鏡的に義歯の摘出を受けた。その 時の所見に依ると気管分忮部, 及右気管枝は略正常であ るが，それより約 $2 \mathrm{~cm}$ 下方の部より左気管枝は瞢状に 狭くなつて居り, それは主として粘膜の浮腫に基くもの で步ると思われた。との腫脤粘膜を少く圷排して見ると 陶蒋が覞われたので義歯異物でむる事が確実となり, コ カインを塗布して粘膜を収縮させた上で鉗子によつて容 易に異物を摘出した。写真 $\mathrm{IV}$, 摘出後気管枝内を検する に異物介在部の内側壁から肉芽が発生して居るが, 各肺 区域の大口部には予期した程の病変はなく，ただ異物介 
在部より末梢気管枝粘胼の発赤, 膿性分泌物の存在を認 めた，その後順調に経過し，6月14日退室。

\section{総括並に考察}

之を要するに本症例は48才の神経瀨患者が睡眠中に義

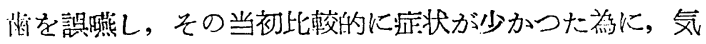
道異物よりも，寧ろ消化管の異物を考えて梌索したが発 見されず，その後咳恻，哭痰，喘鳴，軽度の血痰が現わ 孔冽部疾患の疑を以て梌索し迁余的折を経て, 俱嶼後 3 ヶ月余にして舆物を左気管枝に發見，上気管枝鏡的に摘 出し得た症例である。

気管, 気管枝の義歯異物の報告は本邦に於ても遠藤 (明治28年) 以来其数は必ずしも少くなく，それ等はそ れぞれ医学的に興味がむり, 又教訓を含んでいる。私が 茲に屋上屋を架する報告を, 而子寧万失敗例とも云うべ き報告を敢えてする所以は，諸先候の諭し尽されたかに 思われる気道異物関する警皆にも拘らず，実際には氏 の様な事か起り, 又起るであろらと考㐫られるので, 稍 もすれば発表されずに終る失敗, 困却の症例の赤裸々な 記載が同第の土の御参考になればと希つたからでもる。

さて本症例に就て顧みるに，

（1）当初気道異物の特徵とされている強い痤孌性の哸 嫩発作がなかつた事から, 気道より寧ろ食道異物を考兄 たが，食道の通過障碍がないので，異物は腸に進んだも のと判断したのでめつたが，碓みて湌查の十纷かでなつ た事を遗憾に思つている。交献上では食道異物と䛊られ た気管枝異物の症例は久保氏等の報告がめり, 又無症状 に経過した気道義葴異物例に就ては新井 ${ }^{(2)}$, Clerf ${ }^{(3)}$ 等 の記载がある。

(2) その後の経過に於て見られた咳嫩は連続的な軽度 のもので, 之に喘鳴を伴つて居つた事からして喘息或は 結核性胸部疾患を念頭に置いたが，諸検查の結果否定除 外した。

喘息様の喘鳴 (Asthmoid Wheez) は必ずしも喘息を 意味せず，㞗々気道異物，腫㴡等がその原因となつてい る事は Jackson (4) の指摘する処でむり, 又西方 ${ }^{(5)}$ は気 道義歯異物が 8 ク月間結核として治療された雪を報して 居り，同様な症例は文献上散見せられる妈で注意を要す る事と思われる。

（3）本症例の第 1 回の胸部 $\mathrm{X}$ 線写真は硬度が棃かつた 為と当時異物といらととが念頭に無かつた為に写真の異 物の陰影をそれと判読せず，石灰化した淋巴腺にしては 抢かしいと思らに止つた。それにしても異物介入後 2 ケ 月半を経たとの写真に無気肺を認めなかつた事は些か注
意すべき事であろう。

（4）乙の事は翼物摘出時の気管枝鏡沂見からしても一 見不思議に思われる。即ち異物介在部の気管枝粘膜は強 く堙脤し、為に管脂は輪状使窄して抢つて，その部以 下に強い二次的病変が存在して然るべきである様㮩わ れた。然るに打診上でも，X写真でもその栐な変化は少 く, 発熟も異物が這入つて，56日後微熱程度のものが 出るに至つたに過ざなかつた。との哥はX写真に著明な 变化が見られなかつた尋と共に，異物と気管枝壁との間 にかなり自的に空気の出入する間隙が存在して居つた哥 を意味するもので，内視鏡的観祭は，一方向のみからの 観察に限られ，遠近の判定も，正確を欠いて居つたもの と考えられる。

（稿を終るに臨み，要生園々長光田健輔先生の御校閲 を賜りました事に謝意を表します。又阔山医科大学耳臬 科講師黒佳先生には戔緗摘出並にレントゲン縮少写真を 御提供下さいむして感謝致します。終りに宫田医務課展 及耳约咽喉科主任横田篤三技官の御支援御配慮を厚く御 礼申上ます。)

\section{交献}

(1) 久保: 耳鼠臨休，35:935 昭 15.

（2）荒井：耳息咽唝科，17: 175 昭 19.

(3) Clerf: Ann. Otolary., 33 : 1009 1924.

(4) Jackson: Bronchoscopy, Esophagoscopy and Gastı oscopy. 1934

(5) 西方：愛知医誌 38:1009, 1924

（6）田屐：レプラ，第10巻4号 昭和14年 7 月 
永田論交附図

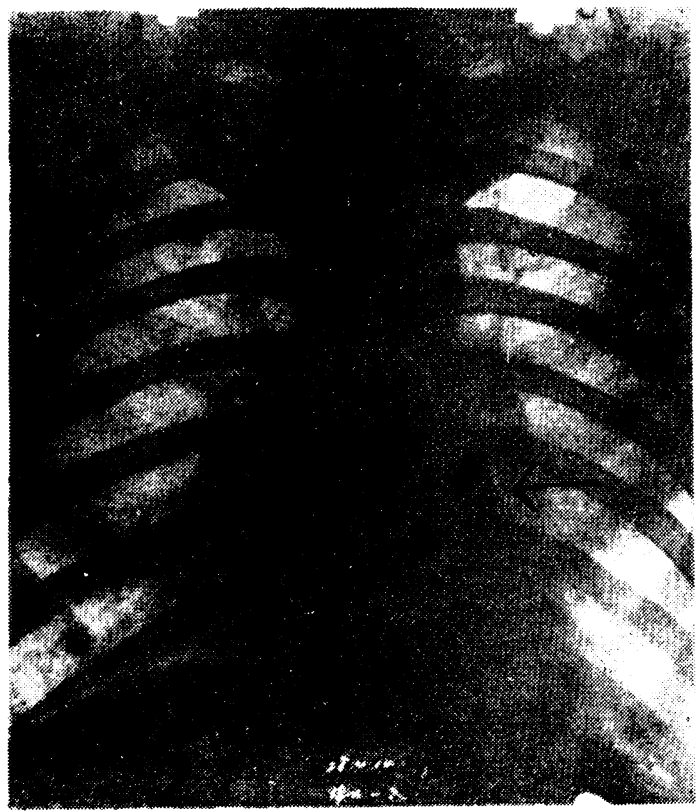

写真 I 矢印は誤認された議啡陰影

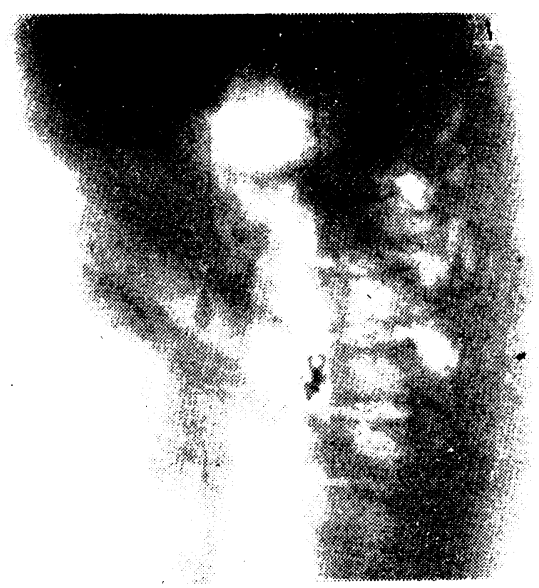

写真III 第二斜位で見た義聎

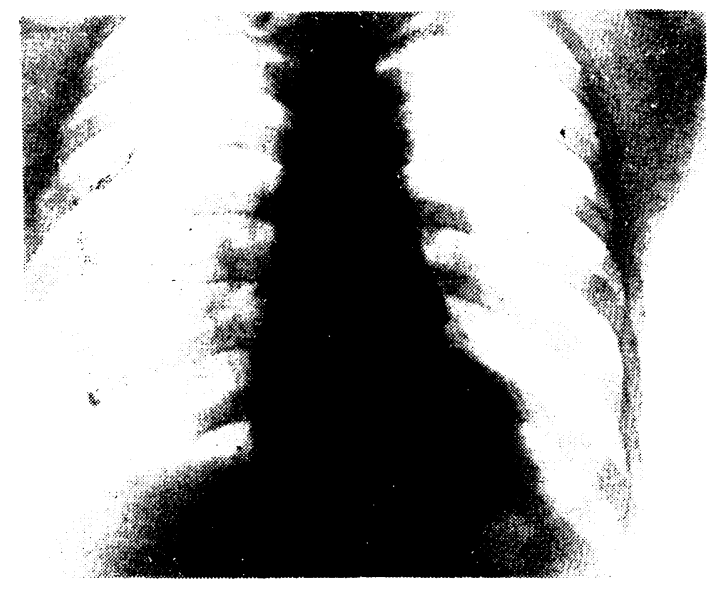

写真』硬度を砸くした後前位

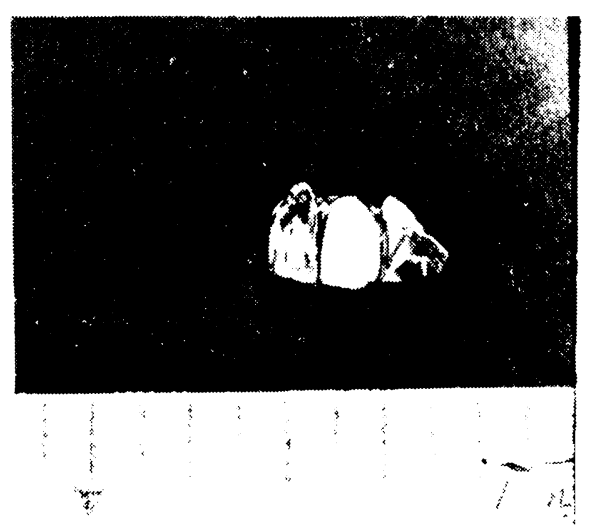

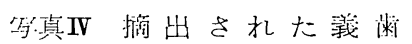

